This item is the archived peer-reviewed author-version of:

Henry Maine and the modern invention of peace

\title{
Reference:
}

Kustermans Jorg.- Henry Maine and the modern invention of peace

Journal of the history of international law = : Revue d'histoire du droit international - ISSN 1388-199X - 20:1(2018), p. 57-88

Full text (Publisher's DOI): https://doi.org/10.1163/15718050-20021014

To cite this reference: https://hdl.handle.net/10067/1487700151162165141 


\section{Henry Maine and the modern invention of peace}

Published in the Journal of the History of International Law, https://doi.org/10.1163/15718050-

20021014

This articles examines Henry Maine's arguments about the prospects of achieving a lasting and comprehensive peace. In a series of lectures on International Law, Maine famously held that "war is as old as mankind but peace is a modern invention." The sentence situates Maine within a long-standing debate on the state of nature. The article reconstructs the meaning of the sentence by interpreting it in light of Maine's broader theoretical framework and comparative-historical approach. An important conclusion of the paper is that Maine never meant the sentence to express a gullible evolutionist perspective on the problem of war and peace. The invention of peace would not, Maine understood, solve the problem of war. Another important finding concerns the centrality of historical arguments to the debate on the state of nature. Proper historical consideration, the paper concludes, does not resolve the problem of the state of nature, but dissolves it.

Henry Sumner Maine; peace; state of nature; comparative history; Axial Age; modernity

\section{Introduction: a promise of historical resolution}

Henry Maine had a knack for pithy formulations. Best-known is his proposition that "[...] the movement of the progressive societies has hitherto been a movement from Status to Contract." ${ }^{1}$ In the same epigrammatic vein, in his lectures on International Law, delivered in 1887 and published posthumously the year after, Maine insisted that "war is as old as mankind but peace is a modern invention." ${ }^{2}$ The purpose of this article is to clarify the meaning of that latter sentence and thus not to primarily to assess its empirical validity. It is important that its meaning be clarified, even if for no other reason than the steady multiplication of unthinking references to it. The British historian Michael Howard used Maine's observation as an epigraph to his popular and widely cited book on The Invention of Peace and ever since scholars can be seen citing Howard citing Maine. ${ }^{3}$ But the

\footnotetext{
${ }^{1}$ Henry Sumner Maine, Ancient Law (London: J.M. Dent \& Sons Ldt. [1861] 1972), 100.

${ }^{2}$ Henry Sumner Maine, International Law: A Series of Lectures Delivered Before the University of Cambridge (London: John Murray 1888), 8.

${ }^{3}$ Michael Howard, The Invention of Peace and the Reinvention of War (London: Profile Books 2001). Hans Van Wees, 'Broadening the Scope: Thinking about Peace in the Pre-Modern World,' in Kurt Raaflaub (ed), Peace in the Ancient World (Malden: Wiley 2016), 158-180, at 158. Ole Wæver, 'Peace and security: two concepts and their relationship', in Stefano Guzzini/Dietrich Jung (eds), Contemporary Security Analysis and Copenhagen Peace Research (London: Routledge 2004), 53-65, at 57. Rachel Kerr, 'Peace', in Austin Harrington/Barbara Marshall/Hans-Peter Müller (eds), Encyclopedia of Social Theory, (London: Routledge 2012), 422-423, at 422. Robert Bernasconi, 'Perpetual Peace and the Invention of Total War', in Christopher Yates/Nathan Eckstrand
} 
citation has become ritualistic, and too often the sentence is taken to express a naïve celebration of modernity's pacifying achievements. This interpretation does not hold water and must be rectified.

The more important reason to reconstruct the meaning of Maine's suggestive sentence is that it may help us come to terms with a long-standing question in political philosophy, which resurfaces time and again, to wit, whether peace or war characterizes the natural condition of mankind. ${ }^{4}$ What Maine offers in this context is a historicizing answer to a philosophical question that had always occasioned recourse to historical conjectures and metaphors. Maine proposes that we should not speculate about the natural condition of human beings, but that we should approach the question empirically and comparatively. We should substitute an empirical, comparative history for an overly conjectural philosophy of history. Maine was not alone in promoting this shift in approach. Nineteenth-century sociologists like Auguste Comte and Herbert Spencer had embarked on similar endeavors ${ }^{5}$ and like Maine, they too had drawn the conclusion that war belonged to earlier historical times, while peace belonged to more recent, modern times. Modern societies had, it appeared somehow, someway - durably overcome mankind's (warlike) natural condition.

This sounds naive again. However, a crucial characteristic of Maine's elaboration of the argument is that it never becomes naïvely evolutionist. The very words by which he stated the thesis (that "peace is a modern invention") indicate so much. Inventions - unlike discoveries - are products of human artifice and there is no predicting which invention will have sticking power. ${ }^{6}$ More importantly, Maine's terse statement implicitly mobilized an entire theoretical apparatus that cautioned against progressivist interpretations of historical developments. Maine brought a

(eds), Philosophy and the Return of Violence: Studies from this Widening Gyre (New York: Bloomsbury 2011), 44-60, at 44. Jorg Kustermans and Erik Ringmar, 'Modernity, boredom and war: a suggestive essay, Review of International Studies 37/4 (2011), 1775-1792.

${ }^{4}$ A recent contribution to the debate is Steven Pinker, The Better Angels of Our Nature: Why Violence Has Declined (London: Penguin Books 2012).

${ }^{5}$ Cf. Richard Vernon, 'Auguste Comte and “Development”: A Note', History and Theory 17 (3) (1978), 323-326.

Robert Perrin, 'Herbert Spencer's Four Theories of Social Evolution', American Journal of Sociology 81 (6) (1976), 1339-1359.

${ }^{6}$ Cf. Leo Strauss, Natural Right and History (Chicago: The University of Chicago Press 1953), 33. 
particular perspective with him to the question of the originality of war and peace - a substantive and methodological perspective grounded in his earlier scholarship on the comparative history of law - and this outlook led him to answer the question in a distinct way. An Ur-form - or elementary form ${ }^{7}$ - of law had arisen in the earliest of times, which had evolved ("from Status to Contract") to accord with changing circumstances. In International Law, Maine intimated that equivalent transformations had evolved in the sphere of war and peace.

But Maine equivocated. He was less radical in his historicization of the problem of war and peace than in his prior historicization of the problem of the law. He did not - not ultimately, not consistently - follow up on his own comparative-historical precepts. He showed a way out of the traditional debate about the nature of the state of nature, but remained himself trapped in it.

The remainder of this article develops this interpretation of Maine's thesis that "war is as old mankind but peace is a modern invention." The purpose is to recover the meaning of that sentence, not as it has evolved through its reception, but as its author originally meant it. My interpretation situates the sentence within its immediate textual context (the lecture series on International Law) and within Maine's broader theoretical framework. To clarify the broader significance of the exercise, however, I first give a plotted account of the state of nature debate first, emphasizing the role that historical arguments have played in it. This sets the stage for the actual reconstruction of Maine' argument about the modernity of peace. Having recovered the meaning of Maine's invention thesis, in a next section, I articulate a few critical comments on it. To this end I draw on recent scholarship about the so-called Axial Age, which shows remarkable parallels with Maine's way of thinking about broad historical patterns of cultural and societal change and also alludes to the invention of peace. However, whereas Maine situates that invention in modern Europe, theorists of the Axial Age situate it much further back in time, at the moment of the first Axial revolutions, typically situated around 500-200 BCE, in Greece, Israel, India and China. A comparison of Maine's

\footnotetext{
${ }^{7}$ Cf. Emile Durkheim and Karen Fields (trans), The Elementary Forms of Religious Life (New York: The Free Press 1995), lix-Ix.
} 
invention thesis with Axial Age scholarship puts me in a position to explain how Maine's

historicization of peace fails to emulate his earlier comparative-historical practice. In a short

conclusion, finally, I return to the question of man's natural condition - whether it should be thought of as a state of war or a state of peace - to clarify precisely how Maine's comparative-historical approach helps us come to terms with it.

\section{Historical arguments about the state of nature}

The concept of a state of nature has been central to political debates for about four centuries now. These debates ultimately concern how politics ought to be organized. Different representations of the state of nature give occasion to different precepts for the organization of political order. There have been those who describe the state of nature as a state of war and there have been those who describe the state of nature as a state of peace. There have also been those who think the concept is useless (or its consequences positively dangerous) and who submit that war and peace are equally primitive. Across the centuries, the three positions have recurred and each position has felt compelled to muster historical evidence in support of its position. As the nature of historical evidence evolved, the positions would evolve with it.

\subsection{A state of war or a state of peace?}

Modern discussion of the problem of war and peace begins with Thomas Hobbes' introduction of the concept of a state of nature and thus with the seventeenth-century imagination of man's natural condition. ${ }^{8}$ Hobbes was an original thinker in his time. ${ }^{9}$ His account of the natural condition of mankind, while not totally unprecedented, was experienced as rather unpalatable by many of his contemporaries. Hobbes' philosophy was criticized more than it was embraced and "[the] main

\footnotetext{
${ }^{8}$ Hans Joas and Wolfgang Knöbl, War in Social Thought: Hobbes to the Present (Chicago: The University of Chicago Press 2013).

${ }^{9} \mathrm{Cf}$. Quentin Skinner, Reason and Rhetoric in the Philosophy of Thomas Hobbes (Cambridge: Cambridge University Press, 1996), 250-326.
} 
target of attack on Hobbes' ideas, other than his specifically religious views, was his state of nature. ${ }^{10}$ Hobbes described the state of nature as a state of war, where hostile attitudes prevailed and life could not but be "solitary, poore, nasty, brutish and short."11 Critics countered that the natural condition was a condition of plenty and innocence, that it was not a state of war but a state of peace. To the extent that we agreed, wrote Samuel Parker, bishop of Oxford, that

The Creation of Man were a Product of the Divine Wisdom or Goodness, his natural State must have been a condition of Peace, and not such a State of War, that should naturally tend to his Misery, Ruine, and utter Destruction. ${ }^{12}$

Scriptural knowledge formed an important source for their displeasure with Hobbes: Hobbes' "description [...] of the condition of human beings before the establishment of civil society [could not be reconciled] with the Biblical account of the original, perfect condition of human beings at the creation $[\ldots . . .]^{13}$

Debate about the bellicose or pacific nature of human being's natural condition would continue into the eighteenth and nineteenth century and in many ways still lingers today. From the eighteenth century, one can think of Jean-Jacques Rousseau and Immanuel Kant. Rousseau agreed with Hobbes' critics that "man in the state of nature [was] peaceful and in a simple [...] way good,"14 but accepted that historical developments had forever corrupted that original state. ${ }^{15} \mathrm{Kant}$, for his part, concurred with Hobbes that the state of nature was indeed a state of war but envisioned the possibility of a gradual and durable escape from it. ${ }^{16}$

\footnotetext{
${ }^{10}$ Helen Thornton, 'Cain, Abel and Thomas Hobbes', History of Political Thought 23 (4) (2002), 611-633 (at 612 ).

${ }^{11}$ Thomas Hobbes and Noel Malcolm (ed.), Leviathan: Volume 2: The English and Latin Texts (i) (Oxford: Clarendon Press 2012), 192.

${ }^{12}$ Samuel Parker, A Discourse of Ecclesiastical Politie: wherein the Authority of the Civil Magistrate over the Consciences of Subjects in Matters of External Religion is Asserted; The Mischiefs and Inconveniences of Toleration are Represented, And all pretenses pleaded in behalf of Liberty of Conscience are Fully Answered (London: Printed for John Martyn 1670), 127-128.

${ }^{13}$ Helen Thornton, State of Nature or Eden: Thomas Hobbes and his Contemporaries on the Natural Condition of Human Beings (Rochester: The University of Rochester Press 2005), 1.

${ }^{14}$ Malcolm Jack, 'One State of Nature: Mandeville and Rousseau', Journal of the History of Ideas 39 (1) (1978), 119-124 (at 121).

${ }^{15}$ Jean-Jacques Rousseau, The Discourse and other early political writings (Cambridge: Cambridge 1997$), 151$.

${ }^{16}$ Immanuel Kant, Pauline Kleingeld (ed) and David Colclasure (trans), Toward Perpetual Peace and Other Writings on Politics, Peace, and History (New Haven and London: Yale University Press 2006), 72.
} 
The nineteenth century witnessed a repetition of these same positions. The Edenic perspective on the state of nature was taken up by many in the nascent peace movement. Thus the Advocate of Peace, the outlet of the American Peace Society, published, in 1852, an 1819 talk by Tristam Burgess "which [could not] fail to be read with interest." While "beast and birds [are by nature] designed for a state of war," Burgess explained, "[man] is not by nature prepared for such a state of war and blood; his natural condition is a state of peace." ${ }^{17}$ Most sociological theorists of the nineteenth century, however, adopted the opposite view, but with a twist. They contemplated a shift in human being's natural condition. Man had once been naturally bellicose, but had now become naturally peaceful. Man's nature was to adapt to circumstances and therefore, as societal conditions evolved, human dispositions evolved with it. Writing in 1922, in a comment on Theodor Mommsen's History of Rome, the Russian historian Michael Rostovtseff summed up the evolution.

The modern world considers the natural condition of life in our society to be the state of peace. War is nothing but a temporary suspending of this natural condition and is regarded as an abnormal state. Free intercourse between different nations is normal; restrictions and limitations of the rights of foreigners are abnormal and require serious reasons [...] But in the ancient world, generally, the natural attitude of one state towards another was that of potential and actual enmity. ${ }^{18}$

The question of the natural condition of mankind could be resolved, it appeared, with reference to comparative-historical evidence.

\subsection{Historical arguments back and forth}

Mind you, though, that history had always been a resource for the protagonists of the state-ofnature debate. Whether in defense of the position that the state of nature was a war-infused condition, in defense of the opposite position that man's natural condition was one of peaceful sociability, or in attack on the very concept of a state of nature, historical arguments were inevitably taken recourse too. Proof of man's natural condition was taken to lie in man's primitive or original condition, and this condition was gleaned from the best sources available. Hobbes himself invoked

\footnotetext{
${ }^{17}$ Tristam Burgess, 'Tristam Burgess on Peace', The Advocate of Peace 10 (4) (1852), 55-58 (at 55).

${ }^{18}$ Cited in David J. Bederman, International Law in Antiquity (Cambridge: Cambridge University Press 2004 ), 17.
} 
scripture, stressing episodes from right after the Fall (when Cain slayed Abel), and also drew on early travel accounts from the Americas, with their depiction of savages and their savagely violent customs. $^{19}$

Both historical references would be contested. Contemporaries contested Hobbes' interpretation of sacred history, arguing that Edenic life at the creation was more original than life after the Fall. ${ }^{20}$ Giambattista Vico, writing in the early eighteenth century, read The Old Testament with a more anthropological purpose in mind, mining it for ethnographic information about the earliest history of mankind, and reading in the Pentateuch a history of "a period of 800 years, the state of nature under the Patriarchs," which did not resemble a war of all against all one bit. If ever there had been a Hobbesian state of nature - during the flood, let's say - this too was a historical condition, describing a particular (and particularly sinful) moment in time. ${ }^{21}$

Rousseau, for his part, would famously dispute Hobbes' interpretation of American travel accounts, insisting that these stories presented the American savages in a corrupted, non-original state. ${ }^{22}$ Joseph de Maistre, writing in the late eighteenth century, questioned the Hobbesian portrayal of the savages of America too. Their current condition, as contemporary ethnographies conveyed them, was not their primitive condition (and neither was, de Maistre cried out, Rousseau's childish imagination of it), but must represent "a degradation of the species, a branch separated we do not know how from the great social tree." Any savage tribe, believed de Maistre, "necessarily descend[ed] from one of the civilized nations that have inhabited the globe."23

\footnotetext{
${ }^{19}$ Beate Jahn, 'IR and the state of nature: cultural origins of a ruling ideology', Review of International Studies 25 (3) (1999), 411-434 (at 418).

${ }^{20}$ Thornton, State of Nature or Eden.

21 John Robertson, 'Sacred History and Political Thought: Neapolitan Responses to the Problem of Sociability After Hobbes', The Historical Journal 56 (1) (2013), 1-29 (citation at 24). Cf. Giambattista Vico and Leon Pompa (ed), The First New Science (Cambridge: Cambridge University Press [1725] 2002), 20.

${ }^{22}$ Cătălin Avramescu and Alistair lan Blyth (trans), Cannibalism: An Intellectual History (Princeton and Oxford: Princeton University Press 2009), 238.

${ }^{23}$ Joseph de Maistre and Richard Lebrun (trans \& ed), Against Rousseau: "On The State of Nature" and "On The Sovereignty of the People" (Montreal and Kingston: McGill-Queen's University Press 1996), $29,32$.
} 
Hobbes and Rousseau (and Kant) made a philosophical argument and marshaled historical evidence in its support. Vico and de Maistre entertained philosophical ambitions too but they endeavored to a greater extent to make a genuine historical argument. ${ }^{24}$ As a result, the whole concept of a state of nature became unmoored, most radically with de Maistre, who thinks the entire concept useless precisely because it is unhistorical, but to a certain degree with Vico too, who well imagines a state of nature, an original condition of mankind, but finds it to be teeming with sociality, customs, and patterns of authority. One result is that neither Vico nor de Maistre desires anymore to identify the state of nature with either a state of war or a state of peace. In the beginning, proper historical consideration leads them to conclude, there was war and peace..$^{25}$ War had happened but peace had happened too.

The nineteenth century thus inherited at least two centuries of debate about the natural condition of mankind. The debate had thus far proved inconclusive - as it was probably fated to prove. But the debate had also shown a gradually more complex and more properly historical engagement with the earliest history of mankind. ${ }^{26}$ Instead of scouting early history for scattered data or paradigmatic episodes, there had been a trend to think more anthropologically about past epochs and distant societies. The nineteenth century continued that trend and took it further. It would not only describe and evaluate past societies in a structured fashion, but it aspired to a similarly comprehensive view on the whole of historical development. The past was patterned. History hung together. It evolved along intelligible lines.

A prominent way to make sense of history's pattern of development was to cut up history in stages, each of which was taken to be marked by a particular type of intellectual framework and

\footnotetext{
${ }^{24}$ Richard Devetak, 'A rival Enlightenment: Critical international theory in historical mode', International Theory 6 (3) (2014), 417-453.

${ }^{25}$ Vico and Pompa, The First New Science, 16.

${ }^{26}$ Cf. Karl Jaspers, The Origin and Goal of History (London: Routledge [1953] 2010), 268. “Of every construction of a total conception we say today: it must be empirically proven. We reject conceptions of events and conditions which are only conjectural. We search hungrily in all directions for the reality of tradition. That which is irreal can no longer survive."
} 
societal organization. ${ }^{27}$ History progressed from one stage to the other. Driving the process, at its most basic, was an increase in complexity - a "gradual natural process." ${ }^{28}$ The militaristic organization of society fitted simpler, less dense social environments. The industrial organization of society fitted more complex social environments. In simpler sociological environments, war was functional and would therefore erupt often. In more complex sociological environments, war would become - and was wagered to have become - dysfunctional and would therefore decline in importance. The state of nature, that is, had been a state of war but was becoming a state of peace.

From war has been gained all that it had to give. [...] [And] what remains to be done, calls for no other agency than the quiet pressure of a spreading industrial civilization on a barbarism that slowly dwindles. ${ }^{29}$

When Henry Maine, writing at the tail end of the nineteenth century, stated that "war is as old mankind but peace is a modern invention," he was clearly contributing to a long-standing debate. There were people in his day - like Tristam Burgess and others in the peace movement - that still posited that "man's natural condition was a state of peace," ${ }^{30}$ but this position Maine was rather impatient with. Like his contemporaries Comte and Spencer (and Adam Ferguson before them), Maine was convinced that a systematic comparative-historical examination offered a way out of what would otherwise remain mere speculation. Also like them, Maine perceived a pattern of historical development and clearly believed that war had been ubiquitous in the (distant) past. He entertained the possibility of peace becoming prevalent in modern times and agreed that no other time had been more receptive to the idea. But Maine's argument was nonetheless different than that of the others. Maine - a student of law, and this will turn out to be important - theorized the development in different terms and was altogether more cautious than most of his contemporaries.

\footnotetext{
${ }^{27}$ Some prominent thinkers of the eighteenth century had already developed a stadial theory of historical development, most notably the protagonists of the Scottish Enlightenment. I nonetheless believe that only during the nineteenth century did stadial thinking evolve to become common sense (and to become as rigid as it became). Cf. Hans Joas and Wolfgang Knöbl, War in Social Thought, 25-37.

${ }^{28}$ Paul Schuurman, 'Herbert Spencer and the paradox of war', Intellecutal History Review 26 (4) (2016), 519-535 (at 531).

${ }^{29}$ Herbert Spencer, The Principles of Sociology in Three Volumes: Vol. II (New York: D. Appleton and Company 1900), 664.

${ }^{30}$ Burgess, 'Tristam Burgess on Peace', 55.
} 
When he delivered his lectures on International Law, Henry Maine had already achieved a solid professional and scholarly reputation. He had occupied an important cabinet position in British India during the 1860 's, serving as Law member of the Viceroy's Council, and had, earlier still, been "catapulted into prominence" with the publication of Ancient Law, a work of comparative-historical scholarship. ${ }^{31}$ His regular contributions to The Saturday Review made him an influential figure within Victorian elite circles.

Even so, when Maine assumed the Whewell professorship in International Law (in the context of which he gave the lectures), he had not been a prominent expert on the subject of the chair that he was now to occupy. Maine did not really identify as an international lawyer and could therefore keep some distance from the - generally evolutionist and progressivist ${ }^{32}$-- intellectual dispositions of the (British) international legal profession. Maine fell back on intuitions and arguments that he had advanced before. These were arguments about the development of the law and they included an argument about the historical origins of the Law of Nations, but they had not been developed with a concern for (the steady progress of) international law in mind.

\subsection{Straightforward sentence, complicated text}

Henry Maine's lectures deal with the topic that had been imposed on him as he had agreed to occupy the Whewell professorship of International Law. Whewell's endowment for the professorship

\footnotetext{
${ }^{31}$ Carl Landauer, 'From Status to Treaty: Henry Sumner Maine's International Law', Canadian Journal of Law and Jurisprudence 15 (2) (2002), 219-254 (at 220).

32 Marrti Koskenniemi, The Gentle Civilizer of Nations: The Rise and Fall of International Law, 1870-1960 (Cambridge: Cambridge University Press 2004), 358. Thomas Skouteris, The Notion of Progress in International Law Discourse (The Hague: T.M.C. Asser Press 2009). T.J.'s Lawrence's Some Disputed Questions explicitly interpreted the meaning of international law in terms of its contribution to the steady evolution of peace. Lawrence, it should be mentioned, was the deputy Whewell chair of International Law when William Vernon Harcourt held it, from 1869 to 1887. But whereas Lawrence presented an unabashedly evolutionist argument, Maine, as will become clear, did not. Cf. Thomas Joseph Lawrence, Some Disputed Questions in Modern International Law, (Cambridge, 1885), 234-277.
} 
had stipulated that its incumbents should make use of the office to "devise such measures as may tend to diminish the causes of war and finally to extinguish war between nations." That international law could contribute to the pacification of world politics was an unspoken assumption of the professorship, and of the field of International Law more generally. ${ }^{33}$ Henry Maine too shared the assumption but in a rather complex way. If peace was a modern creation, its creation apparently tied in with the development of international law. The question is how.

Let me again quote the sentence that we are concerned with, but this time in the context of the paragraph of which it forms part. The paragraph comes after a long exposition of the return of war to European society after the period of European peace that had begun in 1815 and ended in 1853. In 1851 there had still been the Exhibitions of Art and Industry in the Crystal Palace in London, giving the impression that "strife in arms was to be superseded by competition in the peaceful arts, controversy was to be conducted by literary agencies, ${ }^{134}$ but then the Crimean war had erupted. What is more, the atmosphere of the World Exhibition stood in stark contrast with the "intrusion of war into peace ${ }^{\prime 35}$ that had been happening for some time in a number of European societies, which saw national budgets being relocated in favor of defense spending and an exceptionally great number of men being mobilized for military training. It is in this condition of war that Maine found most reason for despair; more, that is, than in the actual hostilities that had erupted with the onset of the Crimean war or with the civil war in the USA or the "frightful struggle of the Indian Mutiny." 36 Maine ends his description of the return of war with an almost despondent reflection on the task that the assumption of the Whewell professorship has burdened him with: "[...] when the forces at work are so enormous, how shall they be controlled, diminished, or reduced by a mere literary agency?" And then comes the paragraph that includes his aphoristic statement about the modernity

\footnotetext{
${ }^{33}$ Cf. Hidemi Suganami, The domestic analogy and world order proposals (Cambridge: Cambridge University Press [1989] 2003), 38, 62-70. Myres McDougal, 'Law and Peace', Denver Journal of International Law and Policy 18 (1) (1989), 1-36.

${ }^{34}$ Maine, International Law, 3.

35 lbid., 5.

${ }^{36}$ Ibid., 4.
} 
of peace. Progressivist optimism, it will immediately become clear, is not actually on evidence here.

Maine writes:

Some consolation may be found in a position which is all the more necessary to insist upon because it is not quite in harmony with the assumption made by some famous writers, presently to be discussed, who are more associated than any others with the origin of International Law. Most of them thought that mankind had started from a condition of innocent peace. It was man's depravity which had interrupted this state and had produced virtually universal and unceasing war. There can be no question that this proposition reverses the truth. It is not peace which was natural and primitive and old, but rather war. War appears to be as old as mankind, but peace is a modern invention. Our intelligence is only just beginning to enable us to penetrate the clouds which rest on the farther verge of history, but what does seem clear to trained observation is the universal belligerency of primitive mankind. Not only is war to be seen everywhere, but it is war more atrocious than we, with our ideas, can easily conceive. ${ }^{37}$

Questions abound. How does the modern invention of peace sit with the return of war that had been sketched just before? Precisely what is that moderns invented when they invented peace, given that it could apparently not stop the return of war? Should we deduce that Maine is content to identify peace with a certain lessening of the intensity and atrocity of war? Is it indicative, in this regard, that Maine finds no more than "some consolation" in the invention of peace? But what then to make of the preceding argument that the "intrusion of war into peace" was more alarming than the actual return of war?

These questions are not being answered immediately. Rather we are treated to an examination of the historical causes of earlier periods of peace. The paradoxical fact here is that these periods and these causes lay in times before what is conventionally considered modernity ${ }^{38}$ and that among the forces for peace that Maine identifies, he mentions ancient practices too. The argument appears to be, at this point, that the moderns ultimately did not invent peace but somehow rediscovered it. Peace was a human concern, of all times and places, and human societies had always striven somehow to achieve it. "[At] the beginning of history," ${ }^{39}$ the conditions for

\footnotetext{
${ }^{37}$ Maine, International Law, 7-8 (emphasis added).

${ }^{38}$ The convention view, that is, has modernity begin with the renaissance and the reformation. Cf. Dante Germino, 'Modernity in Western Political Thought', New Literary History 1 (2) (1970), 293-310 (at 296).

${ }^{39}$ Maine, International Law, 9.
} 
achieving peace successfully were unfavorable and the reason had to do, suggests Maine, with the difficulty of integrating political authority. Authority was difficult to organize and thus to maintain over large swaths of territory. Ancient history may be imperial history, but the reach of ancient empires was always fragile. But when an empire did manage to establish itself, rapacious though its motivation will have been (i.e., to achieve splendor and receive revenue), it would pacify the regions that it lorded over. "[No one] could say how much war they extinguished by the prohibition, which they undoubtedly carried out, of hostilities among the various sub-divisions of their subjects." ${ }^{40}$ The Egyptian, Assyrian, Median, Persian, Chinese and Indian empires are listed as examples. The bellicose condition of a fragmented European continent served as evidence too: in fragmented Europe old controversies may lose their original force and peter out, but new ones always flare up and "Europe is again in bloodshed." ${ }^{\prime 1}$ With the fall of the Roman Empire the pacific influence of that imperial conglomeration had disappeared, and although the pope and the emperor did retain some of Rome's imperial authority and should be seen, according to Maine, as, "unquestionably, on the whole, makers of peace," ${ }^{42}$ the reformation and the ensuing wars of religion brought this to an end.

Paradoxically, the very moment that Europe's Roman peace, which had lingered through the agency of pope and emperor, comes to its definitive end, is also the moment that Europe rediscovers peace. In fact, if I understand Maine correctly, this moment of rediscovery ought to be considered its actual moment of invention. It is at this point, in the aftermath of the reformation and the religious wars that Maine apparently situates the modern invention of peace. In the religious wars of the seventeenth century,

[...] the pope, of course, was necessarily on one side among the combatants, and on the whole the emperor was on the same side. Hence it came about that the great international jurists belonged to the smaller states and were wholly Protestants. The International Law of the Roman Catholic doctors had fallen into suspicion and finally into disrepute. A law with a

\footnotetext{
40 Ibid., 10.

41 Ibid., 11.

42 Ibid., 15.
} 
new sanction was required if states were to obey it, and this is what the new jurists produced. The effect was a rapid mitigation of wars and a rapid decrease in their frequency. ${ }^{43}$ If mankind had shown proof of universal belligerency and of unspeakable cruelty in the ways it waged war, the intervention of Protestant jurists appeared to initiate, or at least inspire, a behavioral break. History witnessed "a rapid mitigation of war and a rapid decrease in their frequency."

Not all connection with the ancient and more particularly with the Roman past was lost. First, Maine mentioned that recorded history shows proof of a certain "sanctity of agreement" among organized groups, or at least a recorded practice of treaty-making among ancient communities, including "treaties of great complexity and antiquity." Beyond individual treaties, Maine also found examples of veritable systems of international law in the historical record, and he points to the Roman jus fetiale as a chief example, emphasizing how this body of law contained within it "extremely express and severe rules which regulate declarations of war." ${ }^{44}$ Second, when with the definitive end of Roman authority in European history, Protestant authors decide to draw up a new, modern system of international law - and here Maine singles out the importance of Hugo Grotius' work - they were explicitly drawing on Roman jus gentium, which they interpreted as a source of Natural Law and for that reason, because it embodied an element of transcendence, was considered eminently "fit for international purposes." 45

Maine had no doubt about the pacific influence of Grotius' work and doctrines. He disagreed with Grotius' about his assumption of a natural condition and about the claim that jus gentium found its origin in any such natural condition, but he was in no doubt about its almost immediate and unambiguously pacifying effect on the world. It "acted on the spirit of belligerency as a charm." ${ }^{46}$ When Louis XIV declared his intent to grant no quarter to his Dutch enemies, Grotius's teachings inspired a "burst of execration from all Europe." This Grotian condemnation - Grotian because

\footnotetext{
${ }^{43}$ Ibid., 16 (emphasis added).

${ }^{44}$ Ibid., 13.

45 Ibid., 21.

46 Ibid., 14.
} 
directly inspired by Grotius' writings - effectively deterred the Sun King's horrendous plan, according to Maine. ${ }^{47}$ In his own century, Maine detected almost verbatim reproduction of Grotius' principles in the various Manuals of War that European and American governments were putting out for their armies to follow; manuals that Maine clearly believed would help abate war.

At the end of his lecture series, ${ }^{48}$ Maine returned to the grand question that the Whewell professorship was ultimately intended to explore. Grotian ideas had been and would remain, unless abandoned, an effective agency for the reduction of war. ${ }^{49}$ War had become less common and less intense as a result of their favorable reception. But this left unanswered the truly important question. Is it possible to achieve peace in the sense that "war between nations would be extinguished"? Maine reviews three possible routes: (1) the general adoption of Christian principles, (2) the general adoption of arbitration in situations of international conflict, and (3) the establishment of a modern "amphiktiony, a combination of neighbouring Powers formed for the purpose of preventing wars," ${ }^{150}$ which he took the alliance of three Emperors (of Germany, AustroHungary and Russia) to be a contemporary equivalent of.

Maine was skeptical about the first route on both theological and historical grounds. He expressed sympathy for the second route but saw many impediments to its useful and general implementation. He was much enamored, however, by the third route. Maine was aware of the unpopularity of his suggestion in Victorian circles. Appreciating the virtues of the League of the Three Emperors was about as peculiar as pointing out the merits of the "Medo-Persian Empire under the Great King." ${ }^{11}$ Victorian opinion had always favored Athenian democracy and disfavored the Persian

\footnotetext{
47 Ibid., 23.

48 Ibid., 207-208.

${ }^{49}$ Scholarship has since established that Grotius' work was less groundbreaking and certainly less pristine than it has become habitual to assume. Cf. Randall Lesaffer, 'The Grotian Tradition Revisited: Change and Continuity in the History of International Law', in J. Crawford and V. Lowe (eds), British Yearbook of International Law (Oxford: Oxford University Press 2002), 103-139 (at 137). Martine Julia Van Ittersum, 'Hugo Grotius: The Making of a Founding Father of International Law', in Anne Orford and Florian Hoffman (eds), The Oxford Handbook of the Theory of International Law (Oxford: Oxford University Press 2016), 82-100 (at 97).

${ }^{50}$ Maine, International Law, 224.

51 Ibid., 225.
} 
empire (and had reproduced Attic preconceptions about their Persian rivals). ${ }^{52}$ Similarly, Victorian opinion generally disliked Europe's Eastern powers. "There is not much constitutionalism, as we understand the word, in Germany and Austro-Hungary, and there is none at all in Russia," Maine understood, "and thus we are led to forget the services they render to mankind by the maintenance of peace and the prevention of bloodshed." ${ }^{53}$ For Maine, however, the example stood and would have to entertained more soberly if the greatest possible extent of peace was to be achieved. He knew that the League of the Three Emperors had largely run its course, but was enchanted by the prospect of it being succeeded by a "combination of the Austro-Hungarian and German Governments with the Government of Italy." 54 This prospect Maine could put hope in. He ends the lectures with a sketch of what may thus be achieved. His imagination was a great deal less vivid than what one might expect from a man who claims the invention of peace for modernity.

War is too huge and too ancient an evil for there to be much probability that it will submit to any one or any isolated panacea. I would even say that there is a strong presumption against any system of treatment which promises to put a prompt and complete end to it. But, like those terrible conflagrations to which it has often been compared, it may perhaps be extinguished by local isolation. In one instance at least, when apparently on the point of bursting out in a most inflammable structure, it has hitherto been kept under..$^{55}$

These final reflections complicate the text terribly. They clarify what Maine meant by peace (and how little he expected of it), but they appear to muddle again the historical claim about the particularly modern invention of peace by returning to what had stood in earlier chapters as an ancient form of organizing peace.

\subsection{The broader theoretical framework}

It should be possible to clear up some of these issues by means of a clarification of what Maine meant by "modern and "ancient" and how he thought about the evolution from the latter to the former. Hans Van Wees has recently expressed the view that "Sir Henry Maine did not explain what

\footnotetext{
${ }^{52}$ Cf. Pierre Briant, Darius Dans L'Ombre D'Alexandre, (Paris: Fayard 2002).

${ }^{53}$ Maine, International Law, 225.

54 Ibid., 227.

55 Ibid., 227-228 (emphasis added).
} 
he meant by 'modern' in [the] context"56 of his invention thesis, but Van Wees is arguably mistaken. Although the meaning of "modern" and "ancient" (and, not unimportantly the description of the historical process which leads from "ancient" to "modern") remains implicit in his lectures on International Law, it is there, and it is generally in tune with what Maine had discussed more elaborately in his classic work on Ancient Law.

\subsubsection{The comparative historical method}

A first point to note is that Maine was wedded to the "comparative historical method." ${ }^{57}$ This has two implications. A first is that Maine risked getting caught in the two tensions that mark this method. There is a tension in comparative history between a version of the method that wants to detect a straightforward, generally applicable 'evolutionist' pattern of development in history versus a version that centers on the analysis of specific practices and institutions (typically thought of as human universals) and the identification of their Ur-form and particular deviations from these. There is also the tension between diffusionism or processualism, on the one hand, and the allure of clear periodization, on the other. The statement that "war is as old mankind but peace a modern invention" suggests an evolutionist position and a fancy for strong periodization, but Maine's overall approach was actually inclined toward processual explanations ${ }^{58}$ and was never singularly concerned with identifying generalizable historical trajectories.

This immediately solves a (minor) paradox. When Maine discovers diplomatic institutions, which attest to a positive valuation of peace ("treaties of great complexity and antiquity", the amphiktiony, jus fetiale), ${ }^{59}$ and discovers the recurrence of war in modern times, this is precisely the kind of finding that what one would expect a comparative historian of Maine's type to come up with.

\footnotetext{
${ }^{56}$ Van Wees, 'Broadening the Scope', 158.

${ }^{57}$ Stefan Collini, Donald Winch and John Burrow, That Noble Science of Politics: A Study in Nineteenth-Century Intellectual History, (Cambridge: Cambridge University Press 1983), 210-219.

58 J.D.Y. Peel, 'Maine as an ancestor of the social sciences', in Alan Diamond (ed), The Victorian Achievement of Sir Henry Maine: A Centennial Appraisal, (Cambridge: Cambridge University Press 1991), 179-184 (at 182).

${ }^{59}$ Cf. Kurt Raaflaub, 'Abhorring War, Yearning for Peace: The Quest for Peace in the Ancient World', in Kurt Raaflaub (ed), Peace in the Ancient World, (Malden: Wiley 2016), 12-42.
} 
War and peace are both human universals, on this view, which admit of an Ur-form and of historical deviations of this Ur-form. The Ur-form forever remains a fallback option, or a life buoy, in periods of distress or turmoil, although these periods can also be the occasion for a new mutation, for the emergence of a new historical form. Maine presented imperial peace as the Ur-form of peace and gruesome, forbidding war as the Ur-form of war. Modern war and peace presented deviations from their original or primitive counterparts.

Maine certainly preferred their modern form, but he was less than confident about their durable achievement. Maine was prone to these types of reservations. He had knowledge about the past and intuitions about the present but he was agnostic about the future. His conjectures always only applied "hitherto" 60 : much as "the movement of the progressive societies had hitherto been a movement from status to contract, ${ }^{\prime 61}$ his speculations about the future of peace ended with the observation that a "terrible conflagration had [...] hitherto been kept under." ${ }^{\text {2 }}$ History contained within it the materials for wide and wild generalizations, but it was a teacher of prudence too.

\subsubsection{The concepts ancient and modern}

A second point to note concerns Maine's definition of the difference between ancient and modern societies or ancient and modern law. He characterized that distinction as one between ancient statuses and modern contracts. By "status" he meant that people, in ancient societies, always participate in social life as members of a group and that this group is thought of in terms of an extended family. Status-thinking originates in the original centrality of households in primitive and archaic societies, households that were ruled by their patriarchs. There was very little societysanctioned law in these types of societies because most of the regulating of people's lives happened by means of patriarchal commands. Whatever society-sanctioned law there existed - e.g., with

\footnotetext{
${ }^{60}$ Alan Diamond, 'Introduction', in Alan Diamond (ed), The Victorian Achievement of Sir Henry Maine: A Centennial Appraisal, (Cambridge: Cambridge University Press 1991), 1-27 (at 23).

${ }^{61}$ Maine, Ancient Law, 100 (emphasis mine).

62 Maine, International Law, 228 (emphasis mine).
} 
respect to the ownership of property or the passing on of property - was intended to ensure the reproduction of these patriarchic structures. Ancient law, argued Maine, "is scanty, because it is supplemented by the despotic commands of the heads of households." ${ }^{63}$ Ancient (public) law, Maine added intriguingly, "is ceremonious, because the transactions to which it pays regard resemble international concerns much more than the quick play of intercourse between individuals. ${ }^{\prime 64}$ I will return to this latter aspect because it pertains to Maine's sober assessment of the prospects for international peace.

Maine spends less time describing modern law. He does tell us that it centers on the notion of contract and that it thus envisions separate individuals freely making mutual arrangements, that they enter and leave as they see fit within the possibilities established by the contract. The adult son or the wife can now own goods in their own right which they could not in a patriarchal, status-based society. Important for our concerns is that the emergence of contract entailed the possibility of reimagining the composition of political societies. In ancient times all political society had to be modeled on kinship relations. Migratory movements - the intrusion of non-kin into society - invited great fears, and if they were to be managed, if migrants were simply too many to be ignored or expelled, they had literally to be adopted into society. Migrants then feigned themselves to be family members and the legal fiction could not be allowed to be experienced as fictitious - and thus it was not. The "family constantly enlarged by the absorption of strangers within its circle." ${ }^{65}$ Contractual principles did away with this cumbersome necessity of feigning and make-believe. It now became possible to build political society on relations of contiguity which would eventually occasion, argues Maine, the organizational principle of territorial sovereignty. These remarks establish a connection with his lectures on International Law and help us further understand what he meant with "the modern invention of peace."

\footnotetext{
${ }^{63}$ Maine, Ancient Law, 74.

64 Ibid.

65 Ibid., 18.
} 
As a starting point, there is the observation that Maine dates the early translation of contractual thinking into political practice at precisely the same moment that he situates the first stirrings of the modern invention of peace. Maine situates both in the European middle ages. With respect to the early adoption of contract-thinking and thus the principle of contiguity into political organization, he wrote that "territorial sovereignty [...] was distinctly an offshoot, though a tardy one, of feudalism. This might have been expected à priori for it was feudalism which for the first time linked personal duties, and by consequence personal rights, to the ownership of land." ${ }^{166}$ And with respect to the first stirrings of the modern invention of peace, Maine remarked that the absolute horrendousness of primitive war had first been abandoned in medieval times: "[when] we come to mediæval war these cruelties have disappeared, and, though the suffering of the wounded and of prisoners of war was great, it seems to have been due rather to ignorance and carelessness than to cruelty. ${ }^{67}$ The modern invention of peace begins in the Late Middle Ages coincidental with the emergence of the notion of territorial sovereignty. Neither had matured at that time, but both appeared in potentia. They were being announced, but their arrival was not yet foretold.

Besides this temporal coincidence, Maine drew a more specific connection between the two. He considered territorial sovereignty a historically necessary condition for the welcoming reception of Grotius' principles of international law. A world of territorially sovereign states entails a world of separate and equal states. Maine understood that this was a crucial fiction for the reception of Grotian legal thought to the extent that it presented itself as an emanation, or representation, of natural law. The persuasive power of natural law thinking, that is, depend on an agreement that natural law is in fact applicable to the circumstances to which we are summoned to apply it. Those circumstances must at least resemble the 'natural condition' where natural law was first 'discovered' and where it had been so rewarding. Maine did not believe in any such thing as a natural condition life was social through and through, and if there was a first condition it was that of the patriarchal

\footnotetext{
66 Ibid., 62.

67 Maine, International Law, 9.
} 
household where patria potestas applied - but he did know that the natural condition had long been a powerful imaginary, which typically took the form of unbound individuals (happily) co-existing. For Grotius' principles to become effective, for them "to work on the spirit of belligerency as a charm," it was a precondition that the world had been parceled up in (equally) sovereign states. "[If] the universal suzerainty of an Imperial head had been admitted even in bare theory, the labours of Grotius would have been idle."68

\subsubsection{The shift from ancient to modern}

A third and final point to note about Maine's broader theoretical framework concerns how he conceived legal change to come about. A decent consideration of this aspect is crucial to a sound interpretation of the 'invention argument.' At its most basic, Maine holds that legal change follows from social change: "[...] social necessities and social opinion are always more or less in advance of Law. We may come indefinitely near to the closing of the gap between them, but it has a perpetual tendency to reopen." ${ }^{69}$ Carl Landauer has traced this dynamic for the argument in International Law. "The lectures," he writes, "have a number of dynamic developments, such as the impact of empire, the force of Roman law, and the effort of international law to address technological changes." ${ }^{70}$ The first and third development present social necessities that occasioned legal change, the second exemplifies how shifting social opinions can foster a change in law. But social change does not give automatic occasion to legal change. It requires an agency that interprets the social circumstances and attaches them to relevant legal precepts. Historically, Maine discerned three such "instrumentalities: legal fictions, equity, and legislation" and added that "their historical order is that into which I placed them.. ${ }^{71}$

\footnotetext{
${ }^{68}$ Maine, Ancient Law, 65.

${ }^{69}$ Ibid., 51.

${ }^{70}$ Carl Landauer, 'From Status to Treaty', 251.

${ }^{71}$ Maine, Ancient Law, 15.
} 
Legal fictions refer to "any assumption which conceals, or affects to conceal, the fact that a rule of law has undergone alteration, its letter remaining unchanged, its operation being modified." ${ }^{\prime 2}$ They are taken recourse to when the "desire for improvement" clashes with the "superstitious disrelish for change." Legislation is the process whereby a representative organ legislates, i.e., draws up new laws as it sees fit. With legislation, legal change has become a matter of course. The legitimacy of the ensuing law is wholly grounded in procedural norms. "Its obligatory force is independent of its principles." ${ }^{73}$ Maine did not find much application for the practice of legislation in the international realm. The international domain, for him, did not achieve a sufficient density of interaction yet. The meeting of sovereign states was more akin to the meeting of heads of households in ancient societies than it was to the meeting of a parliamentary assembly or even a government cabinet in modern domestic settings. Meetings were sparse, the laws that governed them scanty and tilted toward the ceremonial. But there was a third instrumentality for legal change, Equity, which was a thorough improvement on legal fictions and a necessary alternative for legislation, which the structural arrangement of the international realm did afford the application of. Equity refers to the "theory of a set of legal principles, held to be entitled by their intrinsic superiority to supersede the older law." ${ }^{14}$ Equity has its impact on the law (and society more generally) through the agency of an elite, intellectual minority, which elaborates a transcendent standard and works for its acceptance.

Although he does not name it so, Equity is, on Maine's account, the very instrumentality by which Grotius introduced new principles of international law after the religious wars. Maine says as much, when he avers that "the Law of Nations, as framed [in terms of natural law] by the jurists who were its authors [Grotius, Pufendorf, Vattel], spread over the world not by legislation, but by $a$ process of an earlier date." ${ }^{75}$ Maine is very clear that these Protestant jurists misinterpreted the

\footnotetext{
72 Ibid., 16.

73 Ibid., 17.

74 Ibid., 26.

${ }^{75}$ Maine, International Law, 30.
} 
original meaning of the Law of Nations or Jus Gentium, which "had not [...] much colour at first of the meaning which it afterwards acquired"; it was merely "the sum of the common ingredients in the customs of the old Italian tribes" or even "mere market law"76 and never claimed the transcendent value for it that Grotius' interpretation graced it with. A mistake of interpretation this was - although it was not an original mistake; late Roman jurists influenced by "Stoical doctrine" had begun interpreting the Law of Nations along the same lines - but it was a useful mistake. Precisely by claiming natural authority for it, could it legitimize a set of legal rules where there was no overriding sovereign to legislate those rules, and could it, because it assumed the pretense of being supra-legal, of being "a moral and, to some extent a religious, system," the modern invention of peace.

\subsection{The invention of a distinctly modern peace}

One could object at this point that Maine still failed to clarify the very 'meaning of 'modern' in this context." ${ }^{18}$ We have managed to identify its meaning in chronological terms (announcement in late Middle ages, culmination in Grotius) and we have managed to identify the particularly modern process by which the (re-)invention of peace came about (Equity, with invocation of a naturalized jus gentium). But it is still unclear if the modern invention of peace so reconstructed, implied an argument about a simultaneous change in the very nature or meaning of peace, or at least a redefinition of its relationship to war.

I do in fact think that Maine's International Law contains the argument that modern peace differed in nature from ancient peace. He does not state the distinction explicitly but it emerges from a comparison of his remarks on the pacifying force of the Chinese and other ancient empires, on the one hand, and his remarks on the modern version of the Greek amphiktiony, the League of the Three Emperors, on the other hand.

\footnotetext{
${ }^{76}$ Ibid., 27-28.

77 Ibid., 47.

${ }^{78}$ Van Wees, 'Broadening the Scope', 158.
} 
[About ancient empires] The conventionally revised history of the world begins with the formation of certain great empires, the Egyptian, the Assyrian, the Median, and the Persian. No doubt they were a result rather of man's rapacity than of his humanity. The object of their founders was to gratify ambitious display on a great scale and to increase the area from which they could take their taxes; but nevertheless no one could say how much war they extinguished by the prohibition, which they undoubtedly carried out, of hostilities among the various sub-divisions of their subjects. ${ }^{79}$

[About the alliance of the three Emperors] I refer to the alliance of the three great sovereigns of Eastern Europe which is sometimes called the alliance of the three Emperors, which, however, they themselves do not admit to be in form more than a personal understanding. This alliance [...] is not particularly popular in Western Europe. Perhaps we do it the same injustice, and for the same reason, which as historical students we do to such great territorial aggregates as the Medo-Persian Empire under the Great King. [...] There is not much constitutionalism, as we understand the word, in Germany and Austro-Hungary, and there is none at all in Russia, and thus we are led to forget the services they render to mankind by the maintenance of peace and the prevention of bloodshed. [...] [The Alliance of the Three Emperors] is not a very large experiment, but it has demanded sacrifices both of money and sentiment. ${ }^{80}$

The difference lies therein that (1) ancient imperial peace centered on one imperial center, whereas modern, imperial peace centers on three imperial centers; and further lies therein that (2) ancient peace was a means to an end, whereas modern peace had become a more intrinsic pursuit. It not only demanded the expense of resources, but demanded a sacrifice of sentiment too. Equity does not only bring about physical peace, but colors our experience of it and invites an intrinsic commitment to it. Equity, by presenting a transcendent ethical demand, creates a sharper distinction between war and peace than would have previously been held. ${ }^{81}$ Maine's despair about the "intrusion of war into peace" suggests so much. At the same time, the argument about "equity" is not an argument about inevitable historical development and thus does not entail a promise of eternal peace. "Equity" is a theory of intellectual minorities and understands itself to remain so, even when the intellectual minority temporally achieves a position of authority and thus becomes an effective agency for peace.$^{82}$ Equity accepts a world of continuing imperfections but attempts to hold it in check and curb

\footnotetext{
79 lbid., 9-10.

80 Ibid., 224-226 (emphasis added).

${ }^{81}$ Cf. Max Scheler, 'The Idea of Peace and Pacifism, Part 1', Journal of the British Society for Phenomenology 7 (3) (1976), 154-166 (at 162).

${ }^{82}$ Cf. Karl Morisson, 'The Holy of Holies was Empty: Robert Bellah's Quest for Wisdom', Contemporary Sociology 41 (6) (2012), 721-732 (at 727-729). Robert Bellah, 'Das Ewig-weibliche: A Reply to Karl Morisson', Contemporary Sociology 41 (6) (2012), 733-738 (at 738).
} 
them for the better. It is in this way that the modern invention of peace retains a "strong presumption against any system of treatment which promises to put a prompt and complete end to [war]." ${ }^{13}$

\section{$4 \quad$ Modern inventions and Axial breakthroughs: a critical appreciation}

An evaluation of Maine's thesis about the modern invention of peace could plausibly have begun with a more detailed examination of the many historical claims that pervade Maine's work, especially of those claims that associate war and peace with particular actors and institutions. One would like to know more about the Greek amphiktiony and about the League of the Three Emperors and their precise role - and degree of success - in pacifying their environments. One would also want to have a more rounded account of the nature, achievements and limits of the pacifying projects of the Assyrian, Persian and Chinese empires. Reversely, one is curious about the exact evidence for the atrociousness of primitive warfare that Maine posits so authoritatively. Expansive annotation of Maine's International Law would help appraise the work, but that is not a track that I will pursue here. The primary purpose of this more critical part of the discussion remains to clarify the meaning of Maine's thesis and not to assess its empirical merit.

The focus of the present paper has thus far lain on the clarification of Maine's invention thesis, not on criticizing it. A short footnote, which puts into perspective the novelty of Grotius' international legal thought, formed a partial exception. ${ }^{84}$ Maine singled out the importance of Grotius' scholarship and assigned a particular force to it. This does not mean that Maine was unaware of Grotius' precursors. "[Before] international law fell into the hands of [...] writers [like Grotius]," Maine knew, "it had like most other subjects of thought attracted the attention of the Church." ${ }^{85}$ He made two comments about this "chapter of the Law of Nations which is treated of by

\footnotetext{
${ }^{83}$ Maine, International Law, 8.

${ }^{84} \mathrm{fn} .56$ above.

85 Ibid., 14.
} 
Roman Catholic theological writers." He not only experienced "their use of technical expressions [...] like 'law of nature' and 'natural law'" to be "occasionally perplexing," but also observed that the "International Law of the Roman Catholic doctors had fallen into suspicion and finally into disrepute." ${ }^{86}$ It was only with its Protestant re-interpretation that international law become an effective pacifier.

A law with a new sanction was required if states were to obey it, and this is what the new jurists produced. The effect was a rapid mitigation of wars and a rapid decrease in their frequency. ${ }^{87}$

The new Protestant sanction, that is, furnished pacifying powers on international law. Maine suggests that this pacifying effect found its origin both in doctrinal improvements and in sociological circumstances, but remains somewhat unclear on the relative importance of each or their mutual implication. How one parses the contribution of the doctrinal element and the sociological context to the "modern invention of peace" will influence one's understanding of the invention thesis and, consequently, one's appraisal of it.

A comparison of Maine's invention thesis with the argument about the intellectual and moral breakthroughs of the Axial Age should prove useful at this point. The two theories advance strikingly similar claims and have had to grapple, as a result, with remarkably similar problems. A comparison of the two theories will put me in a position to argue that Henry Maine was ultimately mistaken about the "modern invention of peace" and that - given his earlier approach to comparative history and the important role of the identification of an Ur-form within it - he could have foreseen his own mistake. One is almost led to conclude that the mistake was deliberate.

\subsection{The Axial Age breakthroughs}

\footnotetext{
${ }^{86}$ Ibid., 14-16.

87 Ibid.
} 
The concept of an Axial Age refers to an historical stretch of time which witnessed a "parallelism of spiritual outbursts." ${ }^{88}$ It describes "the point in history which gave birth to everything which, since then, man has been able to do, the point most overwhelmingly fruitful in fashioning humanity." ${ }^{89}$ Karl Jaspers did much to promote the concept of an "Axial Period," which he situated "in the period around 500 B.C., in the spiritual process that occurred between 800 and 200 B.C." and spatially he located in China, India, Palestine and Greece. ${ }^{90}$ He elaborated

Confucius and Lao-tse were living in China, all the schools of Chinese philosophy came into being, including those of Mo-ti, Chuang-tse, Lieh-tsu and a host of others; India produced the Upanishads and Buddha and, like China ran the whole gamut of philosophical possibilities down to skepticism, to materialism, sophism and nihilism; in Iran Zarathustra taught a challenging view of the world as a struggle between good and evil; in Palestine the prophets made their appearance, from Elijah, by way of Isaiah and Jeremiah to Deutero-Isaiah; Greece witnessed the appearance of Homer, of the philosophers - Parmenides, Heraclitus and Plato - of the tragedians, Thucydides and Archimedes. Everything implied by these names developed during these few centuries almost simultaneously in China, India, and the West, without any of these regions knowing the others. ${ }^{91}$

The Axial Age has been described as "the age of criticism": "everywhere one notices attempts to introduce greater purity, greater justice, greater perfection [...] New models of reality are propounded as a criticism of, and alternative to, the prevailing models." ${ }^{\prime 2}$ Another interpretation emphasizes how the Axial Age witnessed "the discovery of transcendence": "[...] the religions and philosophical worldviews developed in the Axial cultures [...] focused on a transcendent realm, a divine higher reality conceived of as a normative criterion for the mundane order of society." ${ }^{93}$

\footnotetext{
${ }^{88}$ Eric Voegelin, Thomas Hollweck (ed \& intro) and Paul Caringella (ed \& intro), What is History? And Other Late Unpublished Writings (Baton Rouge and London: Louisiana State University Press 1990), 40.

89 Jaspers, Origin and Goal of History, 1.

${ }^{90} \mathrm{Ibid}$., 1-2. The dating of the Axial breakthroughs has been contested, including even the possibility and desirability of a precise dating. Jan Assmann, Of God and Gods: Egypt, Israel, and the Rise of Monotheism (Madison: The University of Wisconsin Press 2008), 76-89. Voegelin, What is History?, 44-45. Peter Wagner, 'Palomar's Questions. The Axial Age Hypothesis, European Modernity and Historical Contingency', in Johann Aranason, Shmuel Eisenstadt and Björn Wittrock (eds), Axial Civilizations and World History (Leiden: Brill 2005), 87-106 (at 94).

${ }^{91}$ Jaspers, Origin and Goal of History, 2.

${ }^{92}$ Arlando Momigliano, Alien Wisdom: The Limits of Hellenization (Cambridge: Cambridge University Press 1975), 8-9.

${ }^{93}$ Matthias Jung, 'Embodiment, Transcendence, and Contingency: Anthropological Features of the Axial Age', in Robert Bellah and Hans Joas (eds), The Axial Age and Its Consequences (Cambridge, MA: The Belknap Press of Harvard University Press 2012), 77-101 (at 77).
} 
Robert Bellah has clarified the innovative aspect of the Axial transformations by interpreting them as "essentially the breakthrough of theoretic culture." ${ }^{94}$

Bellah adopts the notion from Merlin Donald's "natural history" of the evolution of culture and cognition. ${ }^{95}$ Before theoretic culture, in Donald's scheme, there was episodic, mimetic and mythic culture (in that order). Episodic cognition concerns one's immediate engagement with the environment-at-hand. Mimetic cultures add an imaginative element to episodic cognition: crucial episodes are remembered, re-imagined and prefigured, with movements and sounds but in the absence of language. Mythic cultures invented language and with language human beings could experience a meaningful relationship not only to distinct episodes, but to a succession of episodes. Human beings began situating themselves in a universe of space and time. Theoretic culture effected a hitherto final shift. It invents alphabets and writing and thus creates external memory. The result was a more "reflective and detached" attitude ${ }^{96}$ Understanding was traded for explanation. Stories were traded for analysis. Metaphors were traded for laws and principles.

These innovations in human cognition could not but have political implications. The Axial breakthroughs "involved the development among important elites of a buffered identity, impervious to the enchanted cosmos," explains Charles Taylor.

This both animated and was rendered firmer by disciplines of thought and conduct. These disciplines in turn aimed not only at the reform of personal conduct, but at reforming and remaking societies so as to render them more peaceful, more ordered more industrious. ${ }^{97}$

The Axial Age breakthrough in human cognition fostered reflexivity and detachment and brought the invention of social meliorism in its wake, including, it appears, the invention of peace. There is some evidence of practical impact: as the powerful Indian king Ašoka became a disciple of the Buddha,

\footnotetext{
${ }^{94}$ Robert Bellah, 'What is axial about the axial age?', European Journal of Sociology 46 (1) (2005), 69-89 (at 78). ${ }^{95} \mathrm{Cf}$. Merlin Donald, Origins of the Modern Mind: Three Stages in the Evolution of Culture and Cognition (Cambridge, MA: Harvard University Press 1991), 356.

${ }^{96}$ Bellah, 'What is axial about the axial age?', 79.

${ }^{97}$ Charles Taylor, 'What Was the Axial Revolution?' in Robert Bellah and Hans Joas (eds), The Axial Age and its Consequences (Cambridge, MA: The Belknap Press of Harvard University Press 2012), 30-46 (at 41); emphasis added.
} 
one of the Axial prophets, he grew aware of the "massive sufferings that his conquests had caused" and began to devote himself "to the zealous study of morality." His successors, truth be told, soon abandoned the project. ${ }^{98}$ The conclusion applies more widely. "Breakthroughs were followed by breakdowns." 99 "The Axial Period [...] ended in failure. History went on." ${ }^{100}$ The breakthrough, to be more precise, was at once temporary and definitive. Breakdowns occurred and would always occur, but a cognitive leap had been made and would never be lost again. "The insights [...] survived. The very failures that followed them stimulated repeated efforts to recover the initial insights, to realize the so far unrealized possibilities." ${ }^{101}$

\subsection{The modern invention of peace as a recovery of the Axial breakthrough}

The substantive parallels between Maine's argument about the invention of peace and scholarly claims about innovations of the Axial Age stand out. Both draw attention to the decisive agency of an elite minority (prophets in the Axial period, jurists in the modern period) which articulates a transcendent standard of morality, to which Maine and scholars of the Axial Age ascribes ameliorative and pacifying powers. There is an argument to be made that Axial Age scholarship subsumes Maine's argument about the modern invention of peace, which it interprets as a recovery, in times of breakdown, of an Axial Age insight. Charles Taylor implies so much when he comments on the affinity between (original) Stoicism and the (Christianized) neo-stoicism of the seventeenth century. Taylor explicitly mentions Hugo Grotius as key figure in the elaboration of "the new conception of moral order which we see emerging in modern natural law theory" and insists that (original, Axial Age) Stoicism was of decisive influence on him and his circles. ${ }^{102}$ Henry Maine was not unaware of the filiation. He explained that the seventeenth-century jurists' interpretation of the law of nations drew heavily on earlier Roman re-interpretations of jus gentium in terms of natural law

\footnotetext{
${ }^{98}$ Raaflaub, 'Abhorring War, Yearning for Peace', 20. For more detail, cf. John Strong, The Legend of King Ašoka: A Study and Translation of the Ašokāvadāna (Princeton: Princeton University Press 1983).

${ }^{99}$ Bellah, 'What is axial about the axial age?', 89.

100 Jaspers, Origin and Goal of History, 20.

101 Bellah, 'What is axial about the axial age?', 89.

102 Taylor, 'What Was the Axial Revolution?', 43.
} 
and likewise knew that Stoic philosophy had had a vital influence on these Roman re-

interpretations. ${ }^{103}$ What Maine did not argue - in contradistinction to at least some scholarship on the Axial Age - was that the invention of peace had already happened, let alone materialized, at these earlier times. Ancient peace, on Maine's account, had never reached beyond the expediency of an imperial peace.

\subsection{A shared orientation and a shared bias}

Henry Maine does not only share an argument with scholars of the Axial Age. He also shares a nonparochial orientation with them. He desired to escape a narrow Eurocentric outlook on historical development. Karl Jaspers experienced this desire too. The latter wrote in the aftermath of Nazi rule and Nazi aggressions. His embrace of the Axial Age - an intellectual breakthrough, definitive of our humanity, happening concomitantly and independently in a variety of world regions - must be read as a direct response to Nazi ideology. In the surprising parallelism of the Axial breakthroughs, Jaspers found proof of a common "transpolitical humanity." Jaspers, that is, "is trying to find a religious basis for human cooperation and solidarity in the modern world." ${ }^{104}$ Maine did obviously not write with the same sense of urgency and the legitimating role of his scholarship for the British imperial endeavor, especially the organization of a system of indirect rule, has been well-documented. ${ }^{105}$ Nevertheless, Maine did insist on finding value in non-Western civilizations. His defense of the Chinese and Medo-Persian empires indicate as much, as does his refusal to think of comparative history in simple evolutionist terms. What is more, Maine took it as a fact that European culture was but a branch of a wider civilizational tree. European cultures, on his view, were members of the

\footnotetext{
103 Maine, Ancient Law, 33.

104 Peter Brickey Lequire, 'The Axial Age Debate as a Political Discourse: Karl Jaspers and Eric Voegelin', Cllo 43 (3) (2014), 295-316.

${ }^{105}$ Karuna Mantena, Alibis of Empire: Henry Maine and the Ends of Liberal Imperialism (Princeton: Princeton University Press 2010).
} 
"Indo-European" or "Aryan family" of cultures. ${ }^{106} \mathrm{~A}$ certain cosmopolitan orientation informed his thought, which it shares with scholarship on the Axial Age.

Underlying that cosmopolitan orientation, and imposing its limitation on it, was an intellectual bias in favor of the very innovations that were being described. Henry Maine identified with the work (and person) of Grotius and favored equity as a source of legal change. Other agencies of change - fiction and legislation - were insufficiently rational. Fiction kept silly superstitions intact. Legislation fetishized procedure and lacked substantive direction. It was bound to be hijacked by our passions, by an uncontrolled "passion for change" ${ }^{107}$ Equity was, on Maine's view, clearly the more reasonable practice. The Axial Age interpretation of a world historical pivot, in terms of the intellectual achievements of a limited numbers of "high civilizations" expresses a similar bias. ${ }^{108}$ One finds this identification of author and object most clearly in Weber's sociology of religion, and its celebration of the Protestant ethic, which Karl Jaspers considered a precursor for his argument about the Axial Age. Weber's sociological texts are littered with scathing remarks about Catholicism and its superstitious commitment to "magic-sacramental" practices. Weber found particular fault with the lesser emphasis on the sermon, and thus on ethical teaching, in Catholic mass as opposed to in Protestant services. ${ }^{109}$

It has been mentioned earlier that Maine argued that the new Protestant international law showed itself a more efficacious pacifier than Catholic international law had been. Maine recognized that "the pope and the emperor" had been "unquestionably, on the whole, makers of peace,"110 but he nonetheless does not identify the Roman Catholic theologians as co-inventors of modern peace.

\footnotetext{
${ }^{106}$ Collini et. al., That Noble Science of Politics, 212.

107 Cf. Henry Sumner Maine, Popular Government: Four Essays (London: John Murray 1886), 129-132.

108 Peter Wagner, 'Palomar's Questions', 90.

${ }^{109}$ Hans Joas, 'The Axial Age Debate as a Religious Discourse', in Robert Bellah and Hans Joas (eds), The Axial Age and its Consequences (Cambridge, MA: The Belknap Press of Harvard University Press 2012), 9-29 (at 1819). For a historical qualification of Weber's claims about the anti-intellectualism of Catholicism, cf. Wolfgang Reinhard, 'Reformation, Counter-Reformation and the Early Modern State: A Reassessment', The Catholic Historical Review 75 (3) (1989), 383-404.

110 Maine, International Law, 15.
} 
The peace of pope and emperor, in Maine's short rendering of it, comes across as an ancient, purely instrumental peace and not as a modern, more heartfelt peace. It lacks the latter's sacrifice of sentiment and is not informed, we are led to believe, by a same transcendent standard of right and wrong.

There have been attempts in Axial Age scholarship to wrest away from too close an identification with and celebration of the Axial breakthroughs. Robert Bellah has often repeated that "nothing is ever lost," by which he means, first, that the Axial breakthrough into theoretic culture will be permanent (the occasional breakdown notwithstanding) but also, second, that mimetic and mythic forms of cognition still play their part in post-Axial times too. Charles Taylor has added a consideration of philosophical anthropology to Bellah's analytical point. "The big question," he writes, "is whether we have gained or lost crucial insights into the human condition through the transformations that [the Axial breakthroughs] have wrought." ${ }^{111}$ Weber appears not to have thought so. Maine equivocates (when he draws attention to the merits of ancient forms of peace) but nonetheless favors the modern form of peace. He does not seem to worry too much about what "crucial insights into the human condition" may so have been lost.

\subsection{A failure of comparative-historical imagination}

Such charge of unconcern may be putting it too dramatically and it does not seem to apply to his account in Ancient Law, where he began his exposition with the Homeric conception of the Law in terms of themistes, a conception that was clearly pre-axial and pre-theoretic. These themistes represented the Ur-form of the Law, which both ancient status and modern contract were (contingent) deviations of. The Ur-form came before ancient and modern forms. Maine speaks of "the primitive condition of mankind" in this context and explains that

in the infancy of the race men could only account for sustained or periodically recurring action by supposing a personal agent. Thus, the wind blowing was a person and of course a divine person; the sun rising, culminating, and setting was a person and a divine person; the

\footnotetext{
${ }^{111}$ Taylor, 'What Was the Axial Revolution?', 44.
} 
earth yielding her increase was a person and divine. As, then, in the physical world, so in the moral. When a king decided a dispute by a sentence, the judgment was assumed to be the result of direct inspiration. The divine agent, suggesting judicial awards to kings or to gods, the greatest of kings, was Themis. ${ }^{112}$

We are clearly in the realm of myth here and if one dug deeper in the Homeric poems oneself, or in archeological evidence, one would probably find a mimetic dimension in this early, pre-axial practice of the Law as well.

But that, or the validity of Maine's understanding of the themistes, must not concern us too much at this moment. The more important point is that Maine does not trace the Ur-form of peace back into mythic times, let alone into mimetic times, in his International Law, which plays out entirely in an axial and post-axial environment. ${ }^{113}$ As a result, Maine ends up identifying the Ur-form of peace with ancient imperial peace which he understands in wholly profane terms, as a matter of sheer expedience. This was Maine's biggest mistake. He did not follow up on his own comparativehistorical precepts. He did not stretch his history of peace far enough back in time. Before the axial breakthrough, and then again before Grotius' reenactment of it, there allegedly was no peace but only war. This does not make sense. Peace will have assumed a different form and a different function in mimetic and mythic culture, but it is highly implausible that it did not exist. ${ }^{114}$ In his account of the history of war and peace, Maine's comparative-historical imagination failed him.

\section{Conclusion: about the promise of historical resolution}

\footnotetext{
112 Maine, Ancient Law, 2-3.

${ }^{113}$ Maine's reference to the Medo-Persian empire stands as an exception, were it not that arguments have been advanced for the inclusion of Zoroastrianism and the Achaemenid empire into the Axial period. Cf. Johann Arnason, 'Rehistoricizing the Axial Age', in Robert Bellah and Hans Joas (eds), The Axial Age and its Consequences (Cambridge, MA: The Belknap Press of Harvard University Press 2012), 337-365 (at 343-344). ${ }^{114}$ Iver Neumann has recently traced the evolution of diplomacy all the way back to practices of non-conflictual inter-group relations at the time of the Pleistocene. Cf. Iver Neumann, 'Diplomatic Cooperation: An Evolutionary Perspective', in Dirk Messner and Silke Weinlich (eds), Global Cooperation and the Human Factor in International Relations (London: Routledge 2016), 225-245.
} 
Debate about the state of nature may prove forever inconclusive. Ever since the concept entered our political-philosophical debates, there has been fundamental disagreement about the nature of the state of nature. Many have identified the state of nature as a state of war. Many others have countered that the state of nature was really a state of peace. Participants in the debate have tried to force a conclusion on it by making reference to what they considered decisive historical evidence, but said evidence would always be questioned again. The nineteenth-century supplanted earlier reference to scattered bits of evidence with a more comprehensive historical framework. Humanity's natural condition has evolved, it submitted. Primitive people dwelled in a state of war, but modern people have achieved a state of peace.

At first sight, Henry Maine agrees with this evolutionist account. What else could he have meant when wrote that "war is as old as mankind but peace is a modern invention"? Closer examination has revealed a more complex argument. In the elaboration of his invention thesis, Maine comes terribly close to the perspective of figures like Giambattista Vico and Joseph de Maistre, who held that man's natural condition was to be in the company of other men, that man was naturally and originally social, that there had always been relations of authority and deference, and that, from the very beginning, there had been war and peace. Maine, that is, discovered peaceoriented institutions and successful pacification in antiquity and foresaw the enduring recurrence of war in modernity.

What this means for the debate on the state of nature is that one should no longer want to resolve the debate. History does not resolve the problem of the state of nature, but dissolves it instead. Maine was not willing to draw that conclusion. He chose to identify modern peace as a more heartfelt peace and could thus meaningfully speak about its modern invention. Vico and de Maistre did welcome the dissolution of the debate. If Maine had followed their more radical suit, he could have improved on their insights. For Vico and de Maistre, war and peace were simply transhistorical occurrences. For Maine, war and peace were transhistorical occurrences too, but they were also 
transhistorical institutions. To develop that insight and thus to reconstruct the changing

(institutional) forms and functions of war and peace - unconcerned by any lingering evolutionist commonplaces - would replace and old and inconcludable debate with a new and more material one. Assessing the philosophical implications of shifting the debate in the direction that I propose, especially for how we think about the organization and justification of political rule, falls outside the bounds of this article. 